\title{
Antihypercholesterolemic and Antioxidative Potential of an Extract of the Plant, Piper betle, and Its Active Constituent, Eugenol, in Triton WR-1339-Induced Hypercholesterolemia in Experimental Rats
}

\author{
Karuppasamy Venkadeswaran, ${ }^{1}$ Arumugam Ramachandran Muralidharan, ${ }^{1}$ \\ Thangaraj Annadurai, ${ }^{1}$ Vasanthakumar Vasantha Ruban, ${ }^{1}$ Mahalingam Sundararajan, \\ Ramalingam Anandhi, ${ }^{1}$ Philip A. Thomas, ${ }^{2}$ and Pitchairaj Geraldine ${ }^{1}$ \\ ${ }^{1}$ Department of Animal Science, School of Life Sciences, Bharathidasan University, Tiruchirappalli, Tamilnadu 620024, India \\ ${ }^{2}$ Institute of Ophthalmology, Joseph Eye Hospital, Tiruchirappalli, Tamilnadu 620001, India
}

Correspondence should be addressed to Pitchairaj Geraldine; gerryarchup@yahoo.co.in

Received 31 October 2013; Accepted 16 December 2013; Published 9 January 2014

Academic Editor: Mao-Hsiung Yen

Copyright (C) 2014 Karuppasamy Venkadeswaran et al. This is an open access article distributed under the Creative Commons Attribution License, which permits unrestricted use, distribution, and reproduction in any medium, provided the original work is properly cited.

\begin{abstract}
Hypercholesterolemia is a dominant risk factor for atherosclerosis and cardiovascular diseases. In the present study, the putative antihypercholesterolemic and antioxidative properties of an ethanolic extract of Piper betle and of its active constituent, eugenol, were evaluated in experimental hypercholesterolemia induced by a single intraperitoneal injection of Triton WR-1339 $(300 \mathrm{mg} / \mathrm{kg}$ b.wt $)$ in Wistar rats. Saline-treated hypercholesterolemic rats revealed significantly higher mean blood/serum levels of glucose, total cholesterol, triglycerides, low density and very low density lipoprotein cholesterol, and of serum hepatic marker enzymes; in addition, significantly lower mean serum levels of high density lipoprotein cholesterol and significantly lower mean activities of enzymatic antioxidants and nonenzymatic antioxidants were noted in hepatic tissue samples from salinetreated hypercholesterolemic rats, compared to controls. However, in hypercholesterolemic rats receiving the Piper betle extract ( $500 \mathrm{mg} / \mathrm{kg}$ b.wt) or eugenol (5 mg/kg b.wt) for seven days orally, all these parameters were significantly better than those in salinetreated hypercholesterolemic rats. The hypercholesterolemia-ameliorating effect was better defined in eugenol-treated than in Piper betle extract-treated rats, being as effective as that of the standard lipid-lowering drug, lovastatin ( $10 \mathrm{mg} / \mathrm{kg}$ b.wt). These results suggest that eugenol, an active constituent of the Piper betle extract, possesses antihypercholesterolemic and other activities in experimental hypercholesterolemic Wistar rats.
\end{abstract}

\section{Introduction}

Hypercholesterolemia is a major socioeconomic problem in common individuals as well as health professionals due to the strong correlation between cardiovascular diseases and lipid abnormalities [1]. The modern lifestyle, with a high fat diet and little physical activity, significantly contributes to hypercholesterolemia and cardiovascular diseases [2]. High levels of low-density lipoprotein (LDL) cholesterol accumulate in the extracellular subendothelial space of arteries; these are highly atherogenic and toxic to vascular cells, leading to atherosclerosis, hypertension, obesity, diabetes, and functional depression in organs such as the liver, heart, and kidneys [3]. Clinical trials have shown that lowering lipids reduces the morbidity and mortality associated with cardiovascular complications [4]. Intensive reduction of LDL-cholesterol levels have also been found to reverse atherosclerosis and decrease the progression of cardiovascular disease $[5,6]$.

Oxidative stress induced by reactive oxygen species (ROS) plays an important role in the etiology of several 
diseases, including atherosclerosis and coronary heart disease $[7,8]$. Oxidative stress contributes to the development of atherosclerosis in the vascular wall through the formation of ROS [6]. Increased formation of free radicals is accompanied by perturbations in antioxidant status, resulting in oxidative damage to cellular components [8]. Hypercholesterolemia is reported to be associated with the oxidative stress that results from the increased production of ROS or impairment of the antioxidant system [9]. This has nurtured research interest in evaluating antioxidant-rich traditional remedies and alternative medicines as potentially efficacious cholesterol-lowering therapies which have few, or no, side-effects.

The Piper betle plant is widely grown in the tropical humid climate of South East Asia and its leaves, with a strong pungent and aromatic flavour, are widely consumed as a mouth freshener. The leaves of Piper betle, which are reported to possess medicinal properties, have been widely used as a traditional medicine for treating several diseases including, catarrhal and pulmonary infections [10]. In a preliminary study by Koff et al. [11], an extract of Piper betle leaves was found to contain several bioactive molecules such as polyphenols, alkaloids, steroids, saponins, and tannins. More recently, an extract of Piper betle was reported to exhibit biological capabilities of detoxification and antioxidative and antimutagenic activities [12]. Eugenol (4-allyl-1-hydroxy-2methoxybenzene), a natural food-flavouring agent found in plant extracts of Piper betle, cinnamon, clove, basil, and nutmeg, has been found to ameliorate oxidative stress by preventing oxidative tissue damage in different experimental models $[1,13,14]$. The efficacy of eugenol was found in human beings to be within the permitted levels by Food and Agricultural Organization/World Health Organization Expert Committee on Food Additives (maximum permitted intake is $2.5 \mathrm{mg} / 100 \mathrm{~g}$ ) [15]. Eugenol is reported to be present in a concentration of $0.32 \%$ in Piper betle [16]; conceivably, this concentration may suffice to exert antioxidant activity. Although Piper betle leaves have been reported to possess antioxidative, antifungal, hypotensive, respiratory, antidepressant, antihelminthic, and antibacterial activities [17], there is currently no information on its putative antihyperlipidemic or antiatherogenic potential.

In the present investigation, an attempt has been made to determine whether an ethanolic extract of Piper betle and its active constituent, eugenol, possess putative serum lipidlowering and antioxidant activities in comparison with that of lovastatin (a commercially available serum lipid-lowering drug) in an experimental animal model of hypercholesterolemia.

\section{Materials and Methods}

2.1. Chemicals. Lovastatin and eugenol (98\%) were purchased from Sigma Chemical Co. (St. Louis, MO, USA). Triton WR-1339 and all the other chemicals and reagents used were of analytical grade and were obtained from Himedia Laboratories (Mumbai, India).
2.2. Experimental Animals. Male albino rats of the Wistar strain (150-200 g) were housed under conditions of controlled temperature $\left(25 \pm 2^{\circ} \mathrm{C}\right)$ with a $12 \mathrm{~h} / 12 \mathrm{~h}$ day-night cycle, during which time they had free access to food and water ad libitum. Animals were maintained per national guidelines and protocols approved by the Institutional Animal Ethical Committee (BDU/IAEC/58/2013/09.04.2013).

2.3. Preparation of Plant Extract. The air-dried leaves of Piper betle variety (Bangala Pan) (100 g) were chopped into fine pieces. These were extracted in $95 \%$ ethanol $(1 \mathrm{~L})$ by using a Soxhlet's apparatus for 72 hours. Extracts were then filtered through Whatman filter paper (no. 1). The solvent was evaporated under reduced pressure at $45^{\circ}$ by using a rotary evaporator for elimination of ethanol, and the dried extract was stored at $4^{\circ} \mathrm{C}$ until further use.

2.4. Experimental Induction of Hypercholesterolemia. Hypercholesterolemia was induced experimentally in $12 \mathrm{~h}$-fasted rats by a single intraperitoneal injection of Triton WR-1339 ( $300 \mathrm{mg} / \mathrm{kg}$ body weight (b.wt.)) dissolved in $0.89 \%$ saline [18]. Forty-eight hours after administration of Triton WR1339, rats exhibited elevated serum levels of total cholesterol and triglycerides; these rats were deemed to be hypercholesterolemic and used for further investigation.

\subsection{Experimental Design}

2.5.1. Treatment Groups. The experimental rats were divided into five treatment groups, each comprising five rats.

Group I. Control rats (not hypercholesterolemic and did not receive any treatment).

Group II. Hypercholesterolemic rats that received only saline orally for 7 days.

Group III. Hypercholesterolemic rats that received lovastatin (10 $\mathrm{mg} / \mathrm{kg}$ b.wt./day) in an aqueous suspension orally for 7 days.

Group IV. Hypercholesterolemic rats that received the Piper betle extract (500 mg/kg b.wt./day) in an aqueous suspension orally for 7 days.

Group V. Hypercholesterolemic rats that received eugenol ( $5 \mathrm{mg} / \mathrm{kg}$ b.wt./day) in $0.5 \%$ peanut oil orally for 7 days.

Saline, lovastatin, Piper betle extract, and eugenol were administered orally by gastric intubation once daily for 7 days. Blood samples were collected from all experimental rats on day 10 (7 days after start of treatment), and, subsequently, serum was separated for subsequent analysis of serum lipid profile parameters and serum hepatic marker enzymes. After collection of the blood samples, all the animals were sacrificed by cervical decapitation; from each animal, the liver was excised and stored at $-80^{\circ} \mathrm{C}$ until subsequent analysis of antioxidant activity and the rate of lipid peroxidation in hepatic tissue samples. 
2.5.2. Preparation of Hepatic Tissue Samples for Analysis. Hepatic tissue (100 mg tissue/mL buffer) was first homoge-

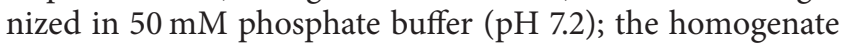
was then centrifuged at $12,000 \times \mathrm{g}$ for $15 \mathrm{mins}$ and the supernatant was used for analysis. The protein concentration in each fraction was determined by the method of Bradford [19], using crystalline bovine serum albumin as a standard.

\subsection{Parameters Analysed}

2.6.1. Blood Glucose Level and Serum Lipid Profile Parameters. Mean levels of blood glucose were measured by the method of Sasaki et al. [20]. In the same samples, mean levels of total cholesterol, triglycerides, and high-density lipoprotein (HDL) cholesterol were determined by standard kits (BioSystems, Spain) following the manufacturer's instructions. The atherogenic index $(\mathrm{AI})$ was calculated as $\mathrm{AI}=$ (total cholesterol - HDL)/HDL. The levels of LDL cholesterol and very low-density lipoprotein (VLDL) cholesterol were calculated by Friedewald's formula [21], the units being expressed as milligrams per decilitre $(\mathrm{mg} / \mathrm{dL})$.

\subsubsection{Activities of Hepatic Marker Enzymes in Serum Samples.} Activities of aspartate aminotransferase (AST) and alanine aminotransferase (ALT) were determined by the method of King [22] and expressed in terms of micromoles of pyruvate liberated per minute per milligram of protein at $37^{\circ} \mathrm{C}$. Alkaline phosphatase (ALP) activity was assayed using disodium phenyl phosphate as substrate [23] and expressed as micromoles of phenol liberated per minute per milligram of protein. Lactate dehydrogenase ( $\mathrm{LDH}$ ) was assayed by the method of King, [24], the principle which is that $\mathrm{LDH}$ converts lactate to pyruvate (aided by coenzyme nicotinamide adenine dinucleotide (NAD)), and pyruvate formed reacts with dinitrophenylhydrazine in $\mathrm{HCl}$ to yield an orangecolored hydrazone complex in alkaline medium, which is measured at $420 \mathrm{~nm}$.

2.6.3. Activities of Antioxidant Enzymes in Hepatic Tissue Samples. The activities of the antioxidant enzymes catalase (CAT), superoxide dismutase (SOD), glutathione peroxidase (Gpx), and glutathione-S-transferase (GST) were determined by standard methods.

CAT. CAT activity was determined by the method of Sinha [25], the principle which is that dichromatic acetic acid is reduced to chromic acetate when heated in the presence of hydrogen peroxide $\left(\mathrm{H}_{2} \mathrm{O}_{2}\right)$, with the formation of perchloric acid as an unstable intermediate. The resulting green colour was read at $590 \mathrm{~nm}$ against a suitable blank on a spectrophotometer. CAT activity was expressed as units per milligram protein (one unit was the amount of enzyme that utilized $1 \mu \mathrm{mol}$ of $\left.\mathrm{H}_{2} \mathrm{O}_{2} / \mathrm{min}\right)$.

SOD. SOD activity (expressed as units/mg protein) was determined by the method of S. Marklund and G. Marklund [26], wherein the degree of inhibition of pyrogallol autooxidation by the sample was measured with the change in absorbance being read at $470 \mathrm{~nm}$ against blank every minute for $3 \mathrm{~min}$ on a spectrophotometer. The enzyme activity was expressed as units/mg protein.

Gpx. The activity of Gpx was determined essentially as described by Rotruck et al. [27], wherein the rate at which glutathione is oxidised by $\mathrm{H}_{2} \mathrm{O}_{2}$ (as catalysed by Gpx present in the sample) is determined by reading the colour developed at $412 \mathrm{~nm}$ on a spectrophotometer. Gpx activity was expressed as units per milligram protein (one unit being the amount of enzyme that converted $1 \mu \mathrm{mol}$ of reduced glutathione (GSH) to the oxidized form of glutathione (GSSG) in the presence of $\mathrm{H}_{2} \mathrm{O}_{2} / \mathrm{min}$ ).

GST. The activity of GST was determined by the method of Habig and Jakoby [28], the principle of which is that GSH conjugates with 1-chloro-2,4-dinitrobenzene (c-DNB; a hydrophilic substrate) which is measured spectrophotometrically at $340 \mathrm{~nm}$. GST activity was expressed as $\mu$ moles of c-DNB formed $/ \mathrm{min} / \mathrm{mg}$ of protein.

\subsubsection{Levels of Nonenzymatic Antioxidants (GSH, Ascorbic Acid, and $\alpha$-Tocopherol) in Hepatic Tissue Samples}

GSH. GSH content ( $\mu \mathrm{g} / \mathrm{mg}$ protein) was estimated by the method of Moron et al. [29], wherein protein in the sample is first precipitated out, followed by addition $4 \mathrm{~mL}$ of $0.3 \mathrm{M}$ $\mathrm{Na}_{2} \mathrm{HPO}_{4}$ (pH 8.0) and $0.5 \mathrm{~mL}$ of $0.04 \%$ (w/v) 5,5-dithiobis2-nitrobenzoic acid to the protein-free supernatant to yield a yellow colour that is read spectrophotometrically at $412 \mathrm{~nm}$.

Ascorbic Acid (Vitamin C). Vitamin C ( $\mu \mathrm{g} / \mathrm{mg}$ protein) was measured by the method of Omaye et al. [30], wherein ascorbate in the sample is oxidized by copper to form dehydroascorbic acid which reacts with 2,4-dinitrophenyl hydrazine to form bis-2,4-dinitrophenyl hydrazine which, in turn, undergoes further rearrangement to form a product with an absorption maximum at $520 \mathrm{~nm}$.

$\alpha$-Tocopherol (Vitamin E). Vitamin E ( $\mu \mathrm{g} / \mathrm{mg}$ protein) was estimated by the method of Desai [31], the principle which is that ferric ions are reduced to ferrous ions in the presence of tocopherol, resulting in the formation of a pink colour that is read spectrophotometrically at $536 \mathrm{~nm}$.

2.6.5. Determination of Lipid Peroxidation in Hepatic Tissues. The mean concentration of malondialdehyde (MDA), a measure of lipid peroxidation, was assayed in the form of thiobarbituric acid-reacting substances (TBARS) by the method of Ohkawa et al. [32]. Briefly, to $0.2 \mathrm{~mL}$ of $8.1 \%$ sodium dodecyl sulphate, $1.5 \mathrm{~mL}$ of $20 \%$ acetic acid ( $\mathrm{pH} 3.5$ ) and $1.5 \mathrm{~mL}$ of $0.81 \%$ thiobarbituric acid aqueous solution were added in succession. To this reaction mixture, $0.2 \mathrm{~mL}$ of the homogenate of hepatic tissue was added. The mixture was then heated in a boiling water bath for $60 \mathrm{~min}$. After cooling to room temperature, $5 \mathrm{~mL}$ of butanol: pyridine $(15: 1, \mathrm{v} / \mathrm{v})$ solutions were added. The mixture was then centrifuged at $2000 \times \mathrm{g}$ for $15 \mathrm{~min}$. The upper organic layer was separated, and the intensity of the resulting pink colour was read 
TABLE 1: Mean levels of blood glucose and of serum lipid profile parameters* in Wistar rats.

\begin{tabular}{|c|c|c|c|c|c|}
\hline $\begin{array}{l}\text { Parameters } \\
\text { tested }\end{array}$ & $\begin{array}{l}\text { Group I } \\
\text { (control) }\end{array}$ & $\begin{array}{c}\text { Group II } \\
\text { hypercholesterolemic, } \\
\text { saline-treated }\end{array}$ & $\begin{array}{c}\text { Group III } \\
\text { hypercholesterolemic, } \\
\text { lovastatin-treated }\end{array}$ & $\begin{array}{c}\text { Group IV } \\
\text { hypercholesterolemic, } \\
\text { Piper betle extract treated }\end{array}$ & $\begin{array}{c}\text { Group V } \\
\text { hypercholesterolemic, } \\
\text { eugenol-treated }\end{array}$ \\
\hline Glucose & $84.5 \pm 2.4$ & $194.1 \pm 2.1^{\mathrm{a}}$ & $144.2 \pm 1.1^{\mathrm{ab}}$ & $149.2 \pm 0.9^{\mathrm{abc}}$ & $141.9 \pm 1.3^{\mathrm{abd}}$ \\
\hline $\begin{array}{l}\text { Total } \\
\text { cholesterol }\end{array}$ & $49.2 \pm 2.4$ & $134.2 \pm 4.7^{\mathrm{a}}$ & $61.5 \pm 1.6^{\mathrm{ab}}$ & $62.2 \pm 2.8^{\mathrm{abc}}$ & $59.2 \pm 3.1^{\mathrm{abc}}$ \\
\hline Triglycerides & $44.6 \pm 2.4$ & $149.6 \pm 2.7^{\mathrm{a}}$ & $59.7 \pm 0.9^{\mathrm{ab}}$ & $63.7 \pm 1.6^{\mathrm{abc}}$ & $53.4 \pm 2.9^{\mathrm{abc}}$ \\
\hline $\begin{array}{l}\text { HDL } \\
\text { cholesterol }\end{array}$ & $29.4 \pm 4.7$ & $20.2 \pm 2.1^{\mathrm{a}}$ & $28.0 \pm 0.2^{\mathrm{ab}}$ & $26.7 \pm 0.7^{\mathrm{ac}}$ & $28.4 \pm 4.2^{\mathrm{abcd}}$ \\
\hline $\begin{array}{l}\text { LDL } \\
\text { cholesterol }\end{array}$ & $13.6 \pm 2.4$ & $109.7 \pm 0.5^{\mathrm{a}}$ & $39.4 \pm 1.3^{\mathrm{ab}}$ & $40.2 \pm 2.7^{\mathrm{ab}}$ & $22.5 \pm 7.2^{\text {acd }}$ \\
\hline $\begin{array}{l}\text { VLDL } \\
\text { cholesterol }\end{array}$ & $4.8 \pm 6.8$ & $35.2 \pm 1.9^{\mathrm{a}}$ & $12.5 \pm 1.0^{\mathrm{ab}}$ & $14.5 \pm 0.2^{\mathrm{abc}}$ & $11.2 \pm 0.5^{\mathrm{abd}}$ \\
\hline A.I. & $0.6 \pm 0.1$ & $4.8 \pm 0.3^{\mathrm{a}}$ & $2.0 \pm 0.3^{\mathrm{ab}}$ & $2.3 \pm 0.2^{\mathrm{b}}$ & $1.3 \pm 0.3^{\mathrm{abcd}}$ \\
\hline
\end{tabular}

*Sampling was done 10 days after induction of hypercholesterolemia and 7 days after start of treatment.

Values represent the mean \pm SD for observations made on five rats in each group.

Units: milligrams per deciliter (except for atherogenic index).

Statistical analysis: One-way analysis of variance (ANOVA), where significant, post hoc testing (least significant difference) was done for intergroup comparisons.

HDL-C: high-density lipoprotein cholesterol, LDL-C: low-density lipoprotein cholesterol, VLDL-C: very low-density lipoprotein-cholesterol, A.I.: atherogenic index.

${ }^{\text {a }}$ Statistically significant difference $(P<0.05)$ when compared with group I values.

${ }^{\mathrm{b}}$ Statistically significant difference $(P<0.05)$ when compared with group II values.

${ }^{\mathrm{c}}$ Statistically significant difference $(P<0.05)$ when compared with group III values.

${ }^{\mathrm{d}}$ Statistically significant difference $(P<0.05)$ when compared with group IV values.

at $532 \mathrm{~nm}$. Tetramethoxypropane was used as an external standard. The level of lipid peroxides was expressed as nmoles of MDA formed/mg protein.

2.6.6. Histopathological Studies. Conventional techniques of paraffin-wax sectioning and haematoxylin-eosin (HE) staining were used for histological studies [33]. Slices of fresh hepatic tissue were cut and fixed in buffered neutral formalin fixative for $24 \mathrm{~h}$. Following fixation, the tissue slices were washed and processed through an ascending series of alcohol $(30 \%$, $50 \%, 70 \%, 90 \%$, and $100 \%$ ), cleared in methyl salicylate, and infiltrated with wax at $57^{\circ} \mathrm{C}$. The hepatic tissue, thus cleared, was embedded in paraffin. Sections of 6-8 $\mu \mathrm{m}$ thickness were cut, stained by aqueous haematoxylin and alcoholic-eosin, and then examined by bright-field microscopy (200x) (Carl Zeiss Axioskop 2 plus; Jena, Germany).

2.6.7. Statistical Analysis. The values are expressed as mean \pm standard deviation (SD) for five animals in each group. Differences between groups were assessed by one-way analysis of variance (ANOVA) using Statistical Package for Social Sciences software package for Windows (version 16.0; IBM Corp., Armonk, NY, USA). If one-way ANOVA yielded significant results, post hoc testing was performed for intergroup comparisons using the least significant difference test. Values were considered statistically significant when $P<0.05$.

\section{Results}

3.1. Blood Glucose Levels in Wistar Rats (Table 1). The mean blood glucose level in hypercholesterolemic, saline-treated (group II) rats was significantly $(P<0.05)$ higher than that in control (group I) rats. In hypercholesterolemic rats treated with lovastatin (group III), Piper betle extract (group IV), or eugenol (group V), significantly $(P<0.05)$ lower mean blood glucose levels were observed when compared to that in saline-treated hypercholesterolemic rats although the levels were still significantly $(P<0.05)$ higher than that in the control rats. The mean blood glucose level was significantly $(P<0.05)$ higher in Piper betle extract-treated hypercholesterolemic rats than that in lovastatin-treated or eugenoltreated hypercholesterolemic rats. However, no significant difference was observed between the mean blood glucose level in lovastatin-treated hypercholesterolemic rats and that in eugenol-treated hypercholesterolemic rats (Table 1).

3.2. Serum Lipid Profile Parameters in Wistar Rats (Table 1). Saline-treated hypercholesterolemic rats showed significantly $(P<0.05)$ higher mean serum levels of total cholesterol, triglycerides, LDL-cholesterol, and VLDL-cholesterol, a significantly higher atherogenic index and a significantly $(P<0.05)$ lower mean level of HDL-cholesterol, when compared to the values in control rats and in lovastatintreated, Piper betle extract-treated, or eugenol-treated hypercholesterolemic rats (Table 1). However, hypercholesterolemic rats treated with lovastatin or Piper betle extract exhibited significantly $(P<0.05)$ higher mean serum levels of total cholesterol, triglycerides, LDL-cholesterol, and VLDLcholesterol, a higher atherogenic index as well as significantly $(P<0.05)$ lower mean serum levels of HDL-cholesterol, when compared to control rats. No significant differences 
TABLE 2: Mean serum levels of hepatic marker enzymes in* Wistar rats.

\begin{tabular}{lccccc}
\hline $\begin{array}{l}\text { Parameters } \\
\text { tested }\end{array}$ & $\begin{array}{c}\text { Group I } \\
\text { (control) }\end{array}$ & $\begin{array}{c}\text { Group II } \\
\text { hypercholesterolemic, } \\
\text { saline treated }\end{array}$ & $\begin{array}{c}\text { Group III } \\
\text { hypercholesterolemic, } \\
\text { lovastatin treated }\end{array}$ & $\begin{array}{c}\text { Group IV } \\
\text { hypercholesterolemic, } \\
\text { Piper betle extract treated }\end{array}$ & $\begin{array}{c}\text { Group V } \\
\text { hypercholesterolemic, } \\
\text { eugenol treated }\end{array}$ \\
\hline AST & $0.8 \pm 0.2$ & $1.8 \pm 0.2^{\mathrm{a}}$ & $1.6 \pm 0.2^{\mathrm{ab}}$ & $1.3 \pm 0.3^{\mathrm{ab}}$ & $1.2 \pm 0.2^{\mathrm{bcd}}$ \\
ALT & $1.2 \pm 0.03$ & $1.8 \pm 0.3^{\mathrm{a}}$ & $1.6 \pm 0.2^{\mathrm{ab}}$ & $1.2 \pm 0.1^{\mathrm{ab}}$ & $1.3 \pm 0.3^{\mathrm{ab}}$ \\
ALP & $2.0 \pm 0.1$ & $3.3 \pm 0.7^{\mathrm{a}}$ & $3.0 \pm 0.1^{\mathrm{a}}$ & $3.2 \pm 0.1^{\mathrm{ab}}$ & $2.8 \pm 0.3^{\mathrm{ab}}$ \\
LDH & $6.9 \pm 0.4$ & $17.2 \pm 0.5^{\mathrm{ab}}$ & $13.4 \pm 0.7^{\mathrm{ab}}$ & $12.2 \pm 0.4^{\mathrm{abc}}$ & $12.5 \pm 0.5^{\mathrm{abc}^{\mathrm{bb}}}$ \\
\hline
\end{tabular}

* Sampling done 10 days after induction of hypercholesterolemia and 7 days after start of treatment.

Values represent the mean \pm SD for observations made on five rats in each group.

Units: aspartate and alanine aminotransferases: $\mu$ moles $\times 10^{-2}$ of pyruvate liberated $/ \mathrm{min} / \mathrm{mg}$ protein.

Alkaline phosphatase: $\mu$ moles $\times 10^{-2}$ of phenol liberated $/ \mathrm{min} / \mathrm{mg}$ protein.

Lactate dehydrogenase: $\mu$ moles $\times 10^{-1}$ of pyruvate formed/minute/mg protein.

Statistical analysis: one-way analysis of variance (ANOVA), where significant, post hoc testing (least significant difference) done for intergroup comparisons. AST: aspartate aminotransferase, ALT: alanine aminotransferase, ALP: alkaline phosphatase, LDH: lactate dehydrogenase.

${ }^{a}$ Statistically significant difference $(P<0.05)$ when compared with group I values.

${ }^{\mathrm{b}}$ Statistically significant difference $(P<0.05)$ when compared with group II values.

${ }^{c}$ Statistically significant difference $(P<0.05)$ when compared with group III values.

${ }^{\mathrm{d}}$ Statistically significant difference $(P<0.05)$ when compared with group IV values.

were observed in these parameters between hypercholesterolemic rats that had been treated with Piper betle extract or with lovastatin (Table 1). Interestingly, eugenol-treated rats exhibited a significantly $(P<0.05)$ lower mean level of total cholesterol than that in lovastatin-treated rats. In addition, the mean serum total cholesterol, triglyceride, and VLDLcholesterol levels in eugenol-treated hypercholesterolemic rats were significantly $(P<0.05)$ lower than those observed in Piper betle extract-treated hypercholesterolemic rats. A very noteworthy finding was that the mean serum levels of triglycerides and VLDL-cholesterol in eugenol-treated hypercholesterolemic rats approximated those in normal rats (Table 1).

3.3. Activities of Hepatic Marker Enzymes in Serum of Wistar Rats (Table 2). The mean activities of serum AST, ALT, ALP, and LDH were found to be significantly $(P<0.05)$ higher in hypercholesterolemic, saline-treated rats than those in control rats. Although hypercholesterolemic rats treated with the Piper betle extract or eugenol exhibited significantly $(P<0.05)$ lower mean activities of these enzymes than those in hypercholesterolemic saline-treated rats, the mean activities of ALT, ALP, and LDH were still significantly higher than those in control rats (Table 2). Interestingly, the mean activity of LDH was significantly $(P<0.05)$ lower in the Piper betle extract-treated and in the eugenol-treated hypercholesterolemic rats than those in the lovastatin-treated hypercholesterolemic rats. No significant differences were observed in the mean serum activities of ALT, ALP, and LDH between hypercholesterolemic rats that had been treated with the Piper betle extract and those that had been treated with eugenol (Table 2).

3.4. Activities of Enzymatic Antioxidants in Hepatic Tissue of Wistar Rats (Table 3). The mean activities of CAT, SOD, Gpx, and GST in the samples of hepatic tissue from hypercholesterolemic saline-treated rats were significantly $(P<0.05)$ lower than those in control rats (Table 3). In hypercholesterolemic rats that had been treated with lovastatin, Piper betle extract, or eugenol, significantly $(P<0.05)$ higher mean activities of these enzymes were noted than those in hypercholesterolemic saline-treated rats; however, these mean enzyme activities remained significantly lower than those in control rats (Table 3). Interestingly, the mean hepatic Gpx activity observed in hypercholesterolemic, eugenoltreated rats was significantly $(P<0.05)$ higher than that in lovastatin-treated hypercholesterolemic rats, while there were no significant differences between these two groups in the mean hepatic activities of CAT and SOD. Also, there were no significant differences in the mean hepatic enzyme activities between hypercholesterolemic Piper betle extract-treated and hypercholesterolemic lovastatin-treated rats (Table 3 ).

\subsection{Concentrations of Nonenzymatic Antioxidants in Hepatic} Tissue of Wistar Rats (Table 3). The mean concentrations of $\mathrm{GSH}$, vitamin $\mathrm{C}$, and vitamin $\mathrm{E}$ in the hepatic tissue samples from hypercholesterolemic, saline-treated rats were significantly $(P<0.05)$ lower than those in control rats (Table 3$)$. However, significantly $(P<0.05)$ higher mean concentrations of these antioxidants were observed in hypercholesterolemic rats that had been treated with lovastatin, Piper betle extract, or eugenol than those in hypercholesterolemic, saline-treated rats. There were no significant differences in the mean values of these parameters between hypercholesterolemic rats that had been treated with the Piper betle extract and those that had been treated with eugenol. Interestingly, the mean hepatic GSH concentrations in these two groups of rats were found to be significantly $(P<0.05)$ higher than that in the hypercholesterolemic, lovastatin-treated rats. In hypercholesterolemic rats that received eugenol, mean hepatic tissue antioxidant concentrations approached those in control rats; in hypercholesterolemic rats that received the Piper betle extract, the mean hepatic vitamin $\mathrm{C}$ level approached that in control rats (Table 3 ). 
TABle 3: Mean activities of enzymatic antioxidants and mean levels of nonenzymatic antioxidants and malondialdehyde in hepatic tissue samples* from Wistar rats.

\begin{tabular}{lccccc}
\hline $\begin{array}{l}\text { Parameters } \\
\text { tested }\end{array}$ & $\begin{array}{c}\text { Group I } \\
\text { (control) }\end{array}$ & $\begin{array}{c}\text { Group II } \\
\text { hypercholesterolemic, } \\
\text { saline treated }\end{array}$ & $\begin{array}{c}\text { Group III } \\
\text { hypercholesterolemic, } \\
\text { lovastatin treated }\end{array}$ & $\begin{array}{c}\text { Group IV } \\
\text { hypercholesterolemic, } \\
\text { Piper betle extract treated }\end{array}$ & $\begin{array}{c}\text { Group V } \\
\text { hypercholesterolemic, } \\
\text { eugenol treated }\end{array}$ \\
\hline SOD & $7.1 \pm 1.4$ & $4.5 \pm 0.5^{\mathrm{a}}$ & $5.0 \pm 0.4^{\mathrm{ab}}$ & $5.3 \pm 0.2^{\mathrm{a}}$ & $5.5 \pm 0.3^{\mathrm{abc}}$ \\
CAT & $53.8 \pm 3.5$ & $40.1 \pm 4.0^{\mathrm{a}}$ & $42.9 \pm 3.2^{\mathrm{b}}$ & $43.8 \pm 0.2^{\mathrm{ac}}$ & $44.6 \pm 5.7^{\mathrm{abd}}$ \\
GPX & $31.3 \pm 5.5$ & $13.4 \pm 1.1^{\mathrm{a}}$ & $20.8 \pm 1.3^{\mathrm{ab}}$ & $21.5 \pm 2.1^{\mathrm{ab}}$ & $22.4 \pm 0.7^{\mathrm{ab}}$ \\
GST & $17.0 \pm 4.4$ & $8.4 \pm 1.0^{\mathrm{a}}$ & $14.4 \pm 1.8^{\mathrm{b}}$ & $14.5 \pm 0.6^{\mathrm{abc}}$ & $14.7 \pm 0.6^{\mathrm{abcd}}$ \\
GSH & $3.3 \pm 0.1$ & $2.0 \pm 0.1^{\mathrm{a}}$ & $2.6 \pm 0.1^{\mathrm{ab}}$ & $2.7 \pm 0.1^{\mathrm{ab}}$ & $2.8 \pm 0.1^{\mathrm{abd}}$ \\
VIT-C & $2.3 \pm 1.4$ & $1.6 \pm 0.6^{\mathrm{a}}$ & $1.7 \pm 0.8^{\mathrm{a}}$ & $1.9 \pm 0.7^{\mathrm{ab}}$ & $1.8 \pm 0.6^{\mathrm{abcd}}$ \\
VIT-E & $1.9 \pm 1.2$ & $1.0 \pm 0.4^{\mathrm{a}}$ & $1.3 \pm 0.6^{\mathrm{ab}}$ & $1.5 \pm 0.1^{\mathrm{abc}}$ & $1.5 \pm 0.7^{\mathrm{bcd}}$ \\
MDA & $1.2 \pm 0.1$ & $3.8 \pm 0.4^{\mathrm{a}}$ & $1.8 \pm 0.3^{\mathrm{ab}}$ & $2.0 \pm 0.2^{\mathrm{abc}}$ & $1.6 \pm 0.1^{\mathrm{acd}}$ \\
\hline
\end{tabular}

* Sampling done 10 days after induction of hypercholesterolemia and 7 days after start of treatment.

Values represent the mean \pm SD for observations made on five rats in each group.

Units: CAT $-\mu$ moles of $\mathrm{H}_{2} \mathrm{O}_{2}$ utilized $/ \mathrm{min} / \mathrm{mg}$ protein.

SOD_units/mg protein.

$\mathrm{Gpx}-\mu$ moles of GSH oxidized/min/mg protein.

GST $-\mu$ moles of c-DNB formed $/ \mathrm{min} / \mathrm{mg}$ protein.

$\mathrm{GSH}$ - microgram of reduced glutathione/mg protein.

Vitamins $\mathrm{C}$ and $\mathrm{E}-$ micrograms/mg protein.

MDA $-\mu$ moles of MDA produced/mg protein.

Statistical analysis: one-way analysis of variance (ANOVA), where significant, post hoc testing (least significant difference) done for intergroup comparisons. CAT: catalase, SOD: superoxide dismutase, Gpx: glutathione peroxidase, GST: glutathione-S-transferase, GSH: reduced glutathione, MDA: malondialdehyde, $\mathrm{H}_{2} \mathrm{O}_{2}$ : hydrogen peroxide, $\mathrm{c}$-DNB: 1-chloro-2,4-dinitrobenzene.

${ }^{a}$ Statistically significant difference $(P<0.05)$ when compared with group I values.

${ }^{\mathrm{b}}$ Statistically significant difference $(P<0.05)$ when compared with group II values.

${ }^{\mathrm{c}}$ Statistically significant difference $(P<0.05)$ when compared with group III values.

${ }^{\mathrm{d}}$ Statistically significant difference $(P<0.05)$ when compared with group IV values.

3.6. MDA Concentrations in Hepatic Tissues of Wistar Rats (Table 3). The mean concentration of MDA in hepatic tissue samples from hypercholesterolemic, saline-treated rats was significantly $(P<0.05)$ higher than that in control rats (Table 3). Although the mean hepatic MDA concentrations in hypercholesterolemic rats that had been treated with lovastatin, Piper betle extract, or eugenol were significantly $(P<$ $0.05)$ lower than that in hypercholesterolemic, saline-treated rats, they remained significantly $(P<0.05)$ higher than that in control rats. Hypercholesterolemic rats treated with eugenol exhibited a significantly lower mean concentration of MDA than those treated with the Piper betle extract. Interestingly, no significant differences were observed in the mean hepatic tissue concentration of MDA in eugenol-treated or Piper betle extract-treated hypercholesterolemic rats, when compared with the mean hepatic tissue concentrations noted in the lovastatin-treated hypercholesterolemic rats.

3.6.1. Histopathological Examination. Sections of hepatic tissue from the experimental groups of rats were stained by $\mathrm{H} \& \mathrm{E}$ and then subjected to histopathological examination by light microscopy (Figure 1). Sections of hepatic tissue from control rats exhibited normal hepatocytes, with normal nuclei and sinusoidal spaces with Kupffer cells (arrows) (Figure 1(a)). In sections from hypercholesterolemic salinetreated rats, revealing loss of normal liver radiating pattern, periportal inflammation with cellular infilteration in central vein (detached line), vacuolated hepatocytes (arrows) with the nucleus pushed to periphery (Figure 1(b)). In hypercholesterolemic lovastatin-treated rats, section showed normal hepatocyte with darkly stained nucleus, (arrows) central vein, and wide sinusoids (Figure 1(c)). In hypercholesterolemic Piper betle extract-treated rats, section showed illustrating few small vacuolated hepatocytes with occasional inflammatory cell infilteration (Figure $1(\mathrm{~d})$ ). In hypercholesterolemic eugenol-treated rats, sections showed normal hepatic architecture, with parenchymal structures preserved (Figure 1(e)).

\section{Discussion}

Triton WR-1339, one of the well-known non-ionic detergent (oxyethylated tertiary octylphenol formaldehyde polymer), that has been widely used to produce acute hyperlipidemia in animal models. Triton WR-1339-induced hypercholesterolemia has been demonstrated to alter the physicochemical properties of lipoproteins, thereby preventing the uptake of lipoproteins from the circulation through extra hepatic tissues resulting in increased level of circulatory lipoproteins in animal models [34]. Triton WR-1339 model being a rapid and convenient system [18] has been extremely employed for screening natural [35-37] or chemical hypolipidemic drugs [38-40] and also to delineate features of cholesterol and triacylglycerol metabolism [41]. In addition, Triton WR-1339 has also been used successfully to study intestinal lipoprotein synthesis in animal models [42]. Hence, the Triton WR-1339 


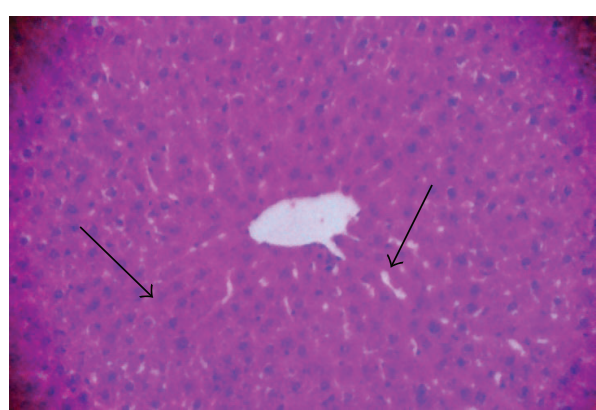

(a)

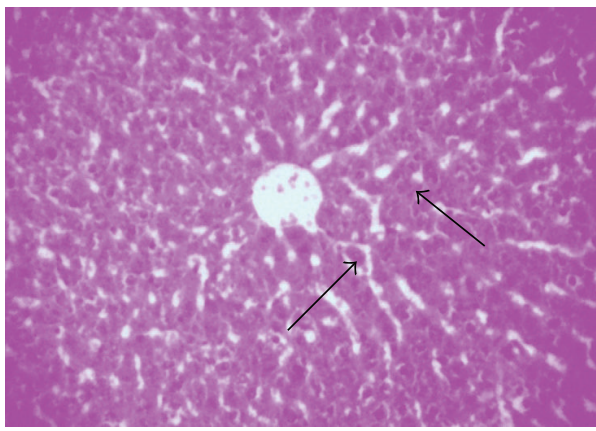

(c)

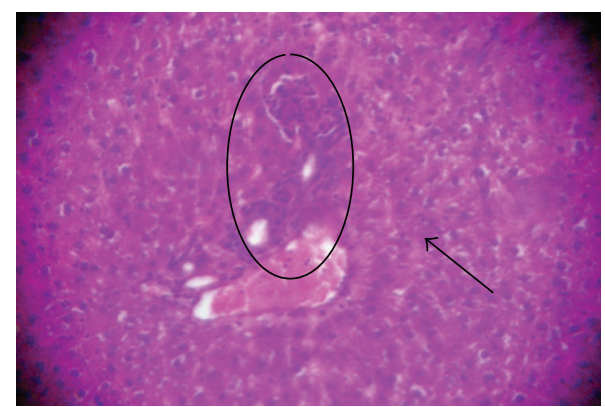

(b)

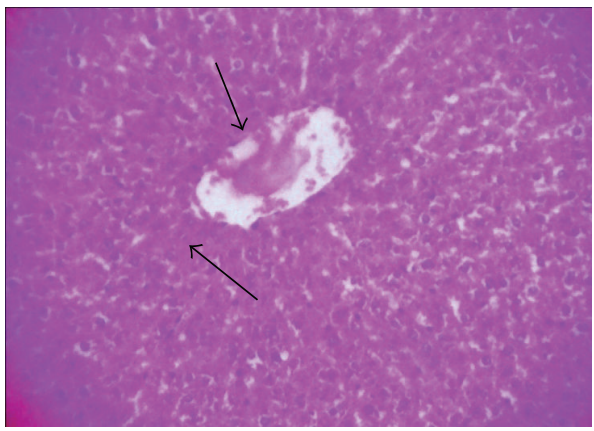

(d)

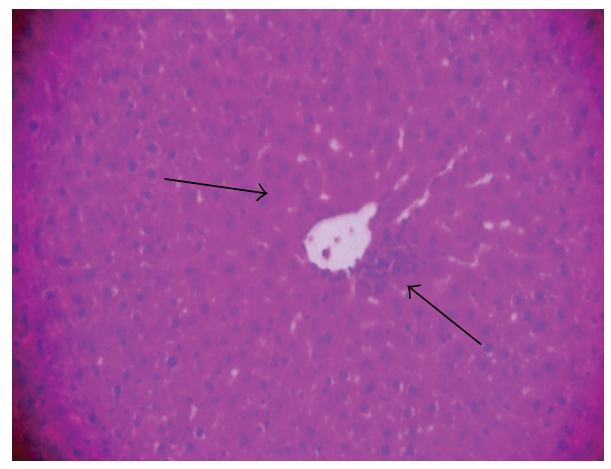

(e)

Figure 1: Histoarchitecture of hepatic tissue Wistar rats. Sections of hepatic tissue from the experimental groups of rats were stained by H\&E and then subjected to histopathological examination by light microscopy (Figure 1). Sections of hepatic tissue from control rats showing central vein with normal hepatocyte, healthy nucleus, and sinusoidal spaces with kupffer cells (arrows) (a). In sections from hypercholesterolemic saline-treated rats, revealing loss of normal liver radiating pattern, periportal inflammation with cellular infiltration in central vein (Marked place), and vacuolated hepatocytes (arrows) with the nucleus pushed to periphery (b). In hypercholesterolemic lovastatin-treated rats, section showed normal hepatocyte with darkly stained nucleus, (arrows) central vein and wide sinusoids (c). In hypercholesterolemic Piper betle extract-treated rats, section showed illustrating few small vacuolated hepatocytes with occasional inflammatory cell infiltration (d). In hypercholesterolemic eugenol-treated rats, sections showed normal hepatic architecture, with parenchymal structures preserved (e).

model has been examined not only as a screening method for antihyperlipidemic agents, but also as a means for elucidating lipid metabolism [43]. In the present study, the putative antihypercholesterolemic effects of an ethanol extract of Piper betle and of one of its active constituents, eugenol, were compared with those of a well-known lipid-lowering drug, lovastatin, in a rodent model of hypercholesterolemia that was induced by Triton WR-1339.

Hyperglycemia and hyperlipidemia are important risk factors for diabetes-accelerated atherosclerosis. The main aim of treatment in patients with hyperlipidemia is to reduce the risk of developing ischemic heart disease or the occurrence of further cardiovascular or cerebrovascular complications [44]. Since hyperlipidemia is frequently associated with hyperglycemia, an attempt was made in the current study to measure the blood glucose level in hypercholesterolemic rats (Table 1). In hypercholesterolemic saline-treated rats, a significantly higher mean blood glucose level than that in control (normal) rats was noted (Table 1). However, the administration of the Piper betle extract or eugenol significantly decreased the blood glucose levels in hypercholesterolemic rats. These results are consistent with 
those of an earlier study in which an extract of the flower of Cassia auriculata significantly decreased serum glucose levels in hyperlipidemic rats [37].

In the present investigation, in hypercholesterolemic rats that had received the Piper betle extract or eugenol, significantly lower mean serum levels of total cholesterol, triglycerides, LDL-cholesterol and VLDL-cholesterol and significantly higher mean serum levels of HDL-cholesterol than those in hypercholesterolemic saline-treated rats were noted. This effect was more pronounced in rats that had received eugenol than in rats that had received the extract of Piper betle. The lipid-lowering effect of leaves of Piper betle and of its active component, eugenol, in an experimental animal model of hypercholesterolemia is probably mediated through inhibition of hepatic cholesterol biosynthesis and reduction of lipid absorption in the intestine. In the present study, the lower mean serum total cholesterol levels were associated with lower levels of the LDL-cholesterol fraction. Serum LDL-cholesterol level is a major and potentially modifiable risk factor of cardiovascular diseases and serves as a target for numerous antihypercholesterolemic therapies. Our finding suggests that the cholesterol-lowering activity of the Piper betle extract is due to enhanced catabolism of LDL-cholesterol through hepatic receptors, as suggested by Khanna et al. [43]. In addition, higher mean serum levels of HDL-cholesterol were noted, which is reported to have a preventive function against atherogenesis. An independent inverse relationship between blood HDL-cholesterol levels and cardiovascular risk incidence has been documented and reported [45]. HDL-cholesterol is commonly termed as "good cholesterol," since it facilitates the mobilisation of triglycerides and cholesterol from plasma to liver, where these are catabolised and eliminated in the form of bile acids.

Elevated plasma levels of triglycerides are found to be associated with an increased incidence of coronary artery disease [46]. Such higher plasma triglyceride levels have been attributed mainly to an increased population of small, dense LDL-cholesterol deposits which are very atherogenic [47] and enhanced cholesteryl ester mass transfer from apolipoprotein B-containing lipoproteins (VLDL-cholesterol and LDLcholesterol) [4]. Triglycerides are also proposed to be a major determinant of cholesterol esterification, its transfer, and HDL-cholesterol remodelling in human plasma [48]. The restoration of catabolic metabolism of triglycerides could be due to an increased stimulation of the lipolytic activity of plasma lipoprotein lipase. These alterations in the levels of serum lipid peroxide and antioxidant status in subjects with high serum total cholesterol and LDL-cholesterol levels and low HDL-cholesterol levels may increase the susceptibility of LDL-cholesterol to oxidation in the circulation.

As enhanced lipid peroxidation leads to higher atherogenicity, it is plausible that antioxidant status should have a major impact not only on the rate of LDL oxidation but perhaps on development of atherosclerosis [49]. A potential risk of atherosclerosis in individuals with high serum lipid levels may be associated with LDL oxidation as a result of increased levels of LDL-cholesterol and decreased antioxidant enzyme activity. In the present study, administration of an extract of Piper betle, or of eugenol, to hypercholesterolemic rats resulted in significantly lower mean serum triglyceride levels than the mean level seen in hypercholesterolemic, saline-treated rats (Table 1). This effect may have been due to enhanced catabolism of triglycerides caused by increased stimulation of plasma lipoprotein lipase activity. Higher mean levels of HDL-cholesterol were also noted in hypercholesterolemic rats that had been treated with lovastatin, Piper betle extract, or eugenol, when compared to the mean level in hypercholesterolemic, saline-treated rats. The lipid-lowering effect brought about by administration of the Piper betle extract and of eugenol might have been due to reactivation of lipolytic enzymes for early clearance of lipids from the circulation in triton-induced hyperlipidemia. Our results are consistent with those of Vallianou et al. [50].

The atherogenic index (ratio of LDL-cholesterol to HDLcholesterol) is also a predictive indicator of cardiovascular disease incidence [35]. Apparently, lowering the atherogenic index is an important measure in reducing the risk of atherosclerosis. In the present study, hypercholesterolemic rats that had been administered Piper betle extract or eugenol exhibited significantly lower mean atherogenic index values than did hypercholesterolemic, saline-treated rats.

Küçükgergin et al. [51] demonstrated that hypercholesterolemia is a primary factor contributing to oxidative damage to hepatocytes, leading to malfunctioning of the liver through microvesicular steatosis and intracellular lipid accumulation. The extent of hepatic damage can be assessed by noting the mean activities of serum transaminases and alkaline phosphatase (ALP) [52]. In the present study, the mean activities of serum AST, ALT, ALP, and LDH were significantly higher in hypercholesterolemic, salinetreated rats than those in control rats (Table 2). However, such elevations in the mean levels of serum AST, ALT, ALP, and LDH enzymes appear to have been prevented in hypercholesterolemic rats that had been treated with the Piper betle extract or with eugenol, since the mean levels were significantly lower than those in hypercholesterolemic, saline-treated rats (Table 2); these observations suggest that the Piper betle extract and eugenol were able to protect the hepatic tissue from hypercholesterolemia-induced oxidative stress-mediated cellular damage. These results are consistent with those of an earlier study, in which the mean serum levels of AST, ALT, ALP, and LDH were found to be significantly lower in rats with Triton WR-1339-induced acute hypercholesterolemia that had been treated with a mushroom extract or with chrysin [53].

Oxygen-free radicals are found to be produced during hypercholesterolemic atherogenesis [54]. Living tissues are endowed with innate antioxidant defense mechanisms through enzymatic and nonenzymatic antioxidants that are involved in the quenching of superoxide anions and $\mathrm{H}_{2} \mathrm{O}_{2}$ [55]. A reduction in the activity of these enzymes is associated with the accumulation of highly reactive free radicals, leading to deleterious effects such as loss of integrity and function of cell membranes [56]. In the present investigation, the mean activities of CAT, SOD, GPx, and GST in hepatic tissue samples from hypercholesterolemic saline-treated rats were significantly $(P<0.05)$ lower than those noted in control 
rats. However, such a decline in the mean activities of CAT, SOD, GPx, and GST appears to have been prevented in hepatic tissue sample from hypercholesterolemic rats that had been treated with lovastatin, the Piper betle extract or eugenol, since the mean activities were significantly higher than those in samples from hypercholesterolemic, salinetreated rats (Table 3 ). The antioxidant activity of eugenol, which has a phenolic structure, has already been evaluated by the extent of protection offered against free radical-mediated lipid peroxidation in both in vitro and in vivo studies [13].

Nonenzymatic antioxidants also play a vital role in protecting cells from oxidative damage. GSH is an important antioxidant in living systems because it is involved in numerous biochemical pathways within the cells. It plays a key role in liver detoxification reactions by maintaining the structural integrity of cell membranes [57]. $\alpha$-tocopherol (Vitamin E), a nonenzymatic antioxidant, is believed to protect biological membranes from oxidative damage by its ability to quench lipid peroxides [58]. It is possible that elevated levels of oxygen-free radicals in hypercholesterolemia may damage the myocardial cell besides affecting the coronary arteries. Ascorbic acid (Vitamin C), the most widely recognized watersoluble antioxidant, prevents the oxidative damage to the cell membrane that is induced by aqueous radicals; it also reduces and regenerates oxidized $\alpha$-tocopherol and lipid peroxides [59]. In the present study, the mean hepatic concentrations of GSH and of vitamins $\mathrm{C}$ and $\mathrm{E}$ were found to be significantly lower in hypercholesterolemic, saline-treated rats than those in control rats (Table 3), possibly due to lipidemic oxidative stress. However, the mean hepatic concentrations of GSH and of vitamins $\mathrm{C}$ and $\mathrm{E}$ were significantly higher in hypercholesterolemic rats that had been treated with lovastatin, Piper betle extract, or eugenol than those in hypercholesterolemic, saline-treated rats (Table 3). No significant differences were noted in these test parameters between lovastatin-treated, Piper betle extract-treated, and eugenol-treated hypercholesterolemic rats. Hence, treatment with the Piper betle extract or eugenol possibly acted by reducing lipidemic oxidative stress, therein permitting these antioxidants to be maintained at near normal levels.

In biological environments, the most favourable substrate for lipid peroxidation is represented by polyunsaturated fatty acids. Hypercholesterolemia-mediated atherosclerosis is associated with an increase in the level of the lipid peroxidation product, malondialdehyde (MDA), which is an index of the level of oxygen-free radicals $[54,60]$; it also reacts with polyunsaturated fatty acids, causing free radical-mediated tissue damage in cellular membranes. The polyunsaturated fatty acids in the cell membrane are protected against lipid peroxidation through endogenous antioxidants such as $\alpha$ tocopherol [61]. A decrease in lipid peroxidation leads to a reduction in arterial wall cholesterol content. Therefore, reduction of atherosclerosis caused by hypercholesterolemia is associated with a decrease in lipid peroxidation, while increased lipid peroxidation is a characteristic feature of hypercholesterolemia; it impairs cell membrane fluidity and alters the activity of membrane-bound enzymes and receptors, resulting in membrane malfunction [55].
Eugenol might be effective in preventing the toxic manifestations produced by increased levels of lipids induced by triton WR-1339. In the present study, the oral administration of eugenol or of the Piper betle extract to hypercholesterolemic rats resulted in significantly lower mean levels of MDA than that in saline-treated hypercholesterolemic rats. The decrease in intensity of lipid peroxidation, as inferred from the lower mean levels of MDA, was possibly due to the free radical-scavenging property of the hydroxyl groups at the seventh position of the eugenol molecule.

Hypercholesterolemia-induced hepatic abnormalities can be further confirmed by histopathological findings. In the present investigation, Triton WR-1339-induced hypercholesterolemic rats that had been treated with saline alone showed marked changes in the liver, ballooning degeneration of the hepatocytes, and occasional collection of chronic inflammatory cells (Figure 1). Deepa and Varalakshmi [62] observed similar fatty changes in the hepatic tissue, which are consistent with the abnormal biochemical parameters observed in the present study. However, treatment with eugenol appeared to ameliorate or prevent the adverse effects, as suggested by the presence of only minimal or partial fatty changes. So also Sudhahar et al. [63] reported that the administration of lupeol and lupeol linoleate to hypercholesterolemic rats resulted in reduction of fatty changes in hepatic tissue.

\section{Conclusion}

In conclusion, the present investigation has demonstrated the putative lipid-lowering effect (by virtue of antioxidant activity) of an ethanolic extract of Piper betle and of eugenol, the major constituent of the Piper betle extract, in Triton WR1339-induced, hypercholesterolemic rats. The lipid-lowering potential and antioxidant capacity of eugenol appeared to be more pronounced than that of the Piper betle extract and as effective as that of the standard lipid-lowering drug, lovastatin. Hence, eugenol may possibly be developed as an alternative cholesterol-lowering drug; however, further molecular studies are required to investigate the mechanism underlying the antihypercholesterolemic effect of this compound. Future studies must focus on the hypolipidemic effect of eugenol under conditions of chronic hypercholesterolemia.

\section{Conflict of Interests}

The authors declare that there is no conflict of interests.

\section{Acknowledgments}

Financial assistance provided by University Grants Commission-Basic Scientific Research (UGC-BSR) in the form of one time grant to the corresponding author is gratefully acknowledged. The instrumentation facility provided by the University Grants Commission-Special Assistance Programme (UGC-SAP) of the Department of Animal Science, Bharathidasan University, is also acknowl-edged. The authors thank Dr. S. Pannerselvam, Professor and Head, Sugarcane 
Research Station, Sirugam-ani-Tiruchirappalli, Tamilnadu, India, for providing the Piper betle variety.

\section{References}

[1] M. A. Morsy and A. A. Fouad, "Mechanisms of gastroprotective effect of eugenol in indomethacin-induced ulcer in rats," Phytotherapy Research, vol. 22, no. 10, pp. 1361-1366, 2008.

[2] J. E. Freedman, "High-fat diets and cardiovascular disease: are nutritional supplements useful?" Journal of the American College of Cardiology, vol. 41, no. 10, pp. 1750-1752, 2003.

[3] K. S. Jain, R. R. Kulkarni, and D. P. Jain, "Current drug targets for antihyperlipidemic therapy," Mini Reviews in Medicinal Chemistry, vol. 10, no. 3, pp. 232-262, 2010.

[4] Å. L. Amundsen, L. Ose, M. S. Nenseter, and F. Y. Ntanios, "Plant sterol ester-enriched spread lowers plasma total and LDL cholesterol in children with familial hypercholesterolemia," American Journal of Clinical Nutrition, vol. 76, no. 2, pp. 338344, 2002.

[5] T. Ichihashi, M. Izawa, K. Miyata, T. Mizui, K. Hirano, and Y. Takagishi, "Mechanism of hypocholesterolemic action of S8921 in rats: S-8921 inhibits ileal bile acid absorption," Journal of Pharmacology and Experimental Therapeutics, vol. 284, no. 1, pp. 43-50, 1998.

[6] W. Shi, M. E. Haberland, M.-L. Jien, D. M. Shih, and A. J. Lusis, "Endothelial responses to oxidized lipoproteins determine genetic susceptibility to atherosclerosis in mice," Circulation, vol. 102, no. 1, pp. 75-81, 2000.

[7] D. L. Tribble, "Antioxidant consumption and risk of coronary heart disease: emphasis on vitamin $\mathrm{C}$, vitamin $\mathrm{E}$, and $\beta$ carotene: a statement for healthcare professionals from the American Heart Association," Circulation, vol. 99, no. 4, pp. 591595, 1999.

[8] E. Hopps, D. Noto, G. Caimi, and M. R. Averna, "A novel component of the metabolic syndrome: the oxidative stress," Nutrition, Metabolism and Cardiovascular Diseases, vol. 20, no. 1, pp. 72-77, 2010.

[9] M. M. M. F. Duarte, J. B. T. Rocha, R. N. Moresco et al., "Association between ischemia-modified albumin, lipids and inflammation biomarkers in patients with hypercholesterolemia," Clinical Biochemistry, vol. 42, no. 7-8, pp. 666-671, 2009.

[10] I. Ahmad, Z. Mehmood, and F. Mohammad, "Screening of some Indian medicinal plants for their antimicrobial properties," Journal of Ethnopharmacology, vol. 62, no. 2, pp. 183-193, 1998.

[11] R. S. Koff, G. Gordan, and S. M. Sabesin, "D-Galactosamine hepatitis hepatocellular injury and fatty liver following a single dose," Proceedings of the Society for Experimental Biology and Medicine, vol. 137, pp. 696-701, 1971.

[12] D. Chakraborty and B. Shah, "Antimicrobial, anti-oxidative and anti-hemolytic activity of Piper betel leaf extracts," International Journal of Pharmacy and Pharmaceutical Sciences, vol. 3, no. 3, pp. 192-199, 2011.

[13] E. Nagababu and N. Lakshmaiah, "Inhibitory effect of eugenol on non-enzymatic lipid peroxidation in rat liver mitochondria," Biochemical Pharmacology, vol. 43, no. 11, pp. 2393-2400, 1992.

[14] H. Kabuto, M. Tada, and M. Kohno, "Eugenol [2-methoxy4-(2-propenyl)phenol] prevents 6-hydroxydopamine-induced dopamine depression and lipid peroxidation inductivity in mouse striatum," Biological and Pharmaceutical Bulletin, vol. 30, no. 3, pp. 423-427, 2007.
[15] World Health Organization, "FAO/WHO expert committee on food additives evaluation of certain food additives and contaminants," Tech. Rep. 683, WHO, Geneva, Switzerland, 1982.

[16] A. M. Rimando, B. H. Han, J. H. Park, and M. C. Cantoria, "Studies on the constituents of Philippine Piper betle leaves," Archives of Pharmacal Research, vol. 9, no. 2, pp. 93-97, 1986.

[17] A. Manigauha, S. Patel, H. Ali, A. Chandy, and M. Uma Maheshwari, "Study the effect of phytochemical constituents of Piper betle leaves extracts on liver disorders by in vivo model," Journal of Pharmacy Research, vol. 2, pp. 353-356, 2009.

[18] P. E. Schurr, J. R. Schultz, and T. M. Parkinson, “Triton-induced hyperlipidemia in rats as an animal model for screening hypolipidemic drugs," Lipids, vol. 7, no. 1, pp. 68-74, 1972.

[19] M. M. Bradford, "A rapid and sensitive method for the quantitation of microgram quantities of protein utilizing the principle of protein dye binding," Analytical Biochemistry, vol. 72, no. 1-2, pp. 248-254, 1976.

[20] T. Sasaki, S. Matzy, and A. Sonal, "Effect of acetic acid concentration on the colour reaction in the O-toluidine boric acid method for blood glucose estimation," Rinsho Kagaku, vol. 1, pp. 346-353, 1972.

[21] W. T. Friedewald, R. I. Levy, and D. S. Fredrickson, "Estimation of the concentration of low-density lipoprotein cholesterol in plasma, without use of the preparative ultracentrifuge," Clinical Chemistry, vol. 18, no. 6, pp. 499-502, 1972.

[22] J. King, "The transferases-alanine and aspartate transaminases," in Practical Clinical Enzymology, D. Van, Ed., pp. 121-138, D. Van Nostrand, London, UK, 1965.

[23] J. King, "The hydrolases-acid and alkaline phosphatases," in Practical Clinical Enzymology, D. Van, Ed., pp. 191-208, D. Van Nostrand, London, UK, 1965.

[24] J. King, "The dehydrogenases or oxidoreductases lactate dehydrogenase," in Practical Clinical Enzymology, D. Van, Ed., D. Van Nostrand, London, UK, 1965.

[25] A. K. Sinha, "Colorimetric assay of catalase," Analytical Biochemistry, vol. 47, no. 2, pp. 389-394, 1972.

[26] S. Marklund and G. Marklund, "Involvement of the superoxide anion radical in the autoxidation of pyrogallol and a convenient assay for superoxide dismutase," European Journal of Biochemistry, vol. 47, no. 3, pp. 469-474, 1974.

[27] J. T. Rotruck, A. L. Pope, H. E. Ganther, A. B. Swanson, D. G. Hafeman, and W. G. Hoekstra, "Selenium: biochemical role as a component of glatathione peroxidase," Science, vol. 179, no. 4073, pp. 588-590, 1973.

[28] W. H. Habig and W. B. Jakoby, "[51] Assays for differentiation of glutathione S-Transferases," Methods in Enzymology, vol. 77, pp. 398-405, 1981.

[29] M. S. Moron, J. W. Depierre, and B. Mannervik, "Levels of glutathione, glutathione reductase and glutathione S-transferase activities in rat lung and liver," Biochimica et Biophysica Acta, vol. 582, no. 1, pp. 67-78, 1979.

[30] S. T. Omaye, J. David Turnbull, and H. E. Sauberlich, "[1] Selected methods for the determination of ascorbic acid in animal cells, tissues, and fluids," Methods in Enzymology, vol. 62, pp. 3-11, 1979.

[31] I. D. Desai, "Vitamin E analysis methods for animal tissues," Methods in Enzymology, vol. 105, pp. 138-147, 1984.

[32] H. Ohkawa, N. Ohishi, and K. Yagi, "Assay for lipid peroxides in animal tissues by thiobarbituric acid reaction," Analytical Biochemistry, vol. 95, no. 2, pp. 351-358, 1979. 
[33] R. A. B. Drury and E. A. Wallington, Wallington, Carleton's Histological Technique, Oxford University Press, New York, NY, USA, 1980.

[34] S. O. Byers, M. Fiedman, and T. Sugiyama, "Triton hypercholesteremia: cause or consequence of augmented cholesterol synthesis," The American Journal of Physiology, vol. 204, pp. 1100-1102, 1963.

[35] H. Harnafi, H. Serghini Caid, N. el Houda Bouanani, M. Aziz, and S. Amrani, "Hypolipemic activity of polyphenol-rich extracts from Ocimum basilicum in Triton WR-1339-induced hyperlipidemic mice," Food Chemistry, vol. 108, no. 1, pp. 205212, 2008.

[36] A. Ansarullah, R. Jadeja, M. Thounaojam, V. Patel, R. Devkar, and A. Ramachandran, "Antihyperlipidemic potential of a polyherbal preparation on Triton WR 1339 (Tyloxapol) induced hyperlipidemia: a comparison with lovastatin," International Journal of Green Pharmacy, vol. 3, no. 2, pp. 119-124, 2009.

[37] P. Vijayaraj, K. Muthukumar, J. Sabarirajan, and V. Nachiappan, "Antihyperlipidemic activity of Cassia auriculata flowers in triton WR 1339 induced hyperlipidemic rats," Experimental and Toxicologic Pathology, no. 1-2, pp. 135-141, 2013.

[38] S.-J. Lee, J.-H. Ko, K. Lim, and K.-T. Lim, “150 kDa glycoprotein isolated from Solanum nigrum Linne enhances activities of detoxicant enzymes and lowers plasmic cholesterol in mouse," Pharmacological Research, vol. 51, no. 5, pp. 399-408, 2005.

[39] G. Shattat, R. Al-Qirim, Y. Al-Hiari et al., "Synthesis and antihyperlipidemic evaluation of $\mathrm{N}$-(benzoylphenyl)-5-fluoro- $1 \mathrm{H}$ indole-2-carboxamide derivatives in Triton WR-1339-induced hyperlipidemic rats," Molecules, vol. 15, no. 9, pp. 5840-5849, 2010.

[40] G. Shattat, T. Al-Qirim, K. Sweidan, M. Shahwan, W. ElHuneidi, and Y. Al-Hiari, "The hypolipidemic activity of novel benzofuran-2-carboxamide derivatives in Triton WR-1339induced hyperlipidemic rats: a comparison with bezafibrate," Journal of Enzyme Inhibition and Medicinal Chemistry, vol. 25, no. 6, pp. 751-755, 2010.

[41] J. J. Ågren, J.-P. Kurvinen, and A. Kuksis, "Isolation of very low density lipoprotein phospholipids enriched in ethanolamine phospholipids from rats injected with Triton WR 1339," Biochimica et Biophysica Acta, vol. 1734, no. 1, pp. 34-43, 2005.

[42] P. R. Holt and A. A. Dominguez, "Triton-induced hyperlipidemia: a model for studies of intestinal lipoprotein production," The American Journal of Physiology, vol. 238, no. 5, pp. G453G457, 1980.

[43] A. K. Khanna, F. Rizvi, and R. Chander, "Lipid lowering activity of Phyllanthus niruri in hyperlipemic rats," Journal of Ethnopharmacology, vol. 82, no. 1, pp. 19-22, 2002.

[44] G. Davey Smith and J. Pekkanen, "Should there be a moratorium on the use of cholesterol lowering drugs?" British Medical Journal, vol. 304, no. 6824, pp. 431-434, 1992.

[45] M. J. Malloy and J. P. Kane, "Medical management of hyperlipidemic states," Advances in Internal Medicine, vol. 39, pp. 603631, 1994.

[46] J. E. Hokanson and M. A. Austin, "Plasma triglyceride level is a risk factor for cardiovascular disease independent of high-density lipoprotein cholesterol level: a meta-analysis of population-based prospective studies," Journal of Cardiovascular Risk, vol. 3, no. 2, pp. 213-219, 1996.

[47] M. A. Austin, J. E. Hokanson, and J. D. Brunzell, "Characterization of low-density lipoprotein subclasses: methodologic approaches and clinical relevance," Current Opinion in Lipidology, vol. 5, no. 6, pp. 395-403, 1994.
[48] T. Murakami, S. Michelagnoli, R. Longhi et al., “Triglycerides are major determinants of cholesterol esterification/transfer and HDL remodeling in human plasma," Arteriosclerosis, Thrombosis, and Vascular Biology, vol. 15, no. 11, pp. 1819-1828, 1995.

[49] M. J. Thomas, "Physiological aspects of low density lipoprotein oxidation," Current Opinion in Lipidology, vol. 11, pp. 297-301, 2000.

[50] I. Vallianou, N. Peroulis, P. Pantazis, and M. HadzopoulouCladaras, "Camphene, a plant-derived monoterpene, reduces plasma cholesterol and triglycerides in hyperlipidemic rats independently of HMG-CoA reductase activity," PLoS ONE, vol. 6, no. 11, Article ID e20516, 2011.

[51] C. Küçükgergin, A. F. AydIn, G. Özdemirler-Erata, G. Mehmetçik, N. Koçak-Toker, and M. Uysal, "Effect of artichoke leaf extract on hepatic and cardiac oxidative stress in rats fed on high cholesterol diet," Biological Trace Element Research, vol. 135, no. 1-3, pp. 264-274, 2010.

[52] D. W. Molander, F. Wroblewski, and J. S. ladue, "Serum glutamic oxalacetic transaminase as an index of hepatocellular integrity," Journal of Laboratory and Clinical Medicine, vol. 6, pp. 831-839, 1955.

[53] R. Anandhi, T. Annadurai, T. S. Anitha et al., "Antihypercholesterolemic and antioxidative effects of an extract of the oyster mushroom, Pleurotus ostreatus, and its major constituent, chrysin, in Triton WR-1339-induced hypercholesterolemic rats," Journal of Physiology and Biochemistry, vol. 69, no. 2, pp. 313-323, 2013.

[54] K. Prasad, "Reduction of serum cholesterol and hypercholesterolemic atherosclerosis in rabbits by secoisolariciresinol diglucoside isolated from flaxseed," Circulation, vol. 99, no. 10, pp. 1355-1362, 1999.

[55] B. Halliwell, "Lipid peroxidation, antioxidants and cardiovascular disease: how should we move forward?" Cardiovascular Research, vol. 47, no. 3, pp. 410-418, 2000.

[56] C. G. Sheela and K. T. Augusti, "Antiperoxide effects of Sallyl cysteine sulphoxide isolated from Allium sativum Linn and gugulipid in cholesterol diet fed rats," Indian Journal of Experimental Biology, vol. 33, no. 5, pp. 337-341, 1995.

[57] C. D. Klaassen, W. M. Bracken, R. E. Dudley, P. L. Goering, G. A. Hazelton, and J. J. Hjelle, "Role of sulfhydryls in the hepatotoxicity of organic and metallic compounds," Toxicological Sciences, vol. 5, no. 5, pp. 806-815, 1985.

[58] M. G. Traber and H. Sies, "Vitamin E in humans: demand and delivery," Annual Review of Nutrition, vol. 16, pp. 321-347, 1996.

[59] B. A. Freeman and J. D. Crapo, "Biology of disease. Free radicals and tissue injury," Laboratory Investigation, vol. 47, no. 5, pp. 412-426, 1982.

[60] K. Prasad and J. Kalra, "Oxygen free radicals and hypercholesterolemic atherosclerosis: effect of vitamin E," American Heart Journal, vol. 125, no. 4, pp. 958-973, 1993.

[61] E. Niki, H. Shimasaki, and M. Mino, Antioxidant-Free Radical and Biological Defence, Gakkai-Shuppan Center, Tokyo, Japan, 1994.

[62] P. R. Deepa and P. Varalakshmi, "Protective effects of certoparin sodium, a low molecular weight heparin derivative, in experimental atherosclerosis," Clinica Chimica Acta, vol. 339, no. 1-2, pp. 105-115, 2004.

[63] V. Sudhahar, S. A. Kumar, and P. Varalakshmi, "Role of lupeol and lupeol linoleate on lipemic-oxidative stress in experimental hypercholesterolemia," Life Sciences, vol. 78, no. 12, pp. 1329$1335,2006$. 


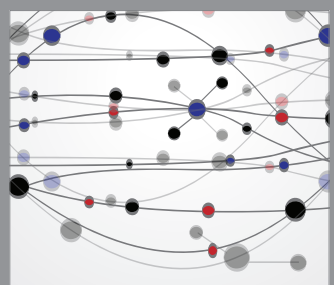

The Scientific World Journal
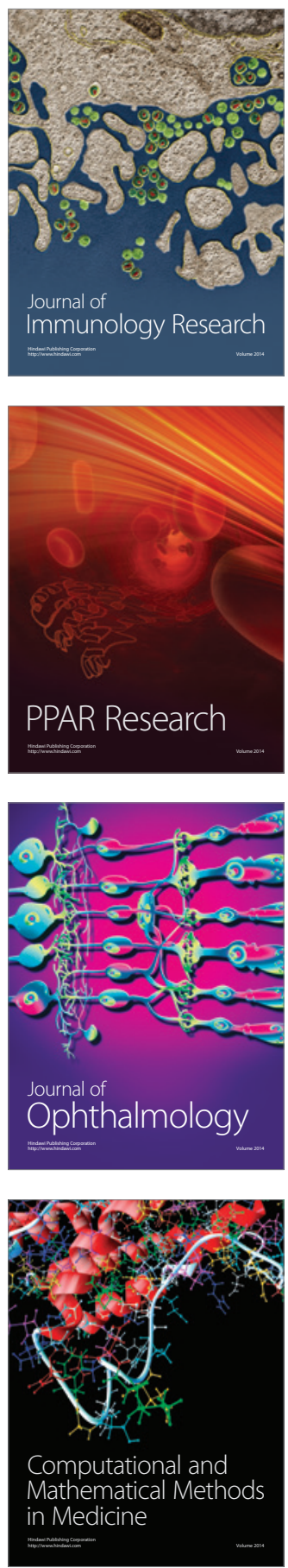

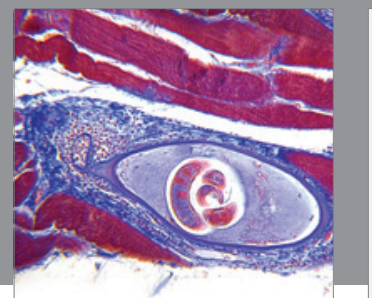

Gastroenterology

Research and Practice
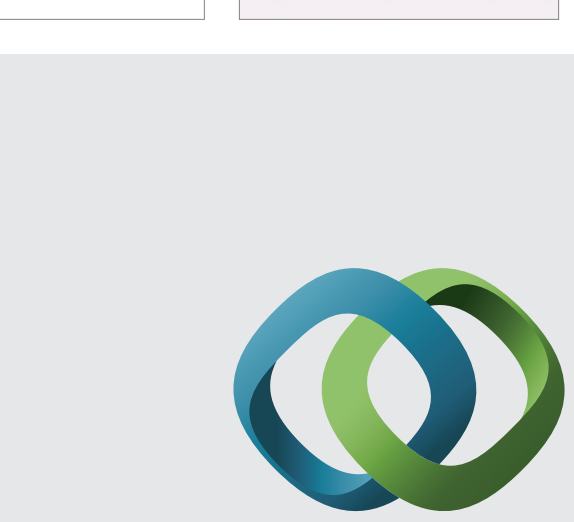

\section{Hindawi}

Submit your manuscripts at

http://www.hindawi.com
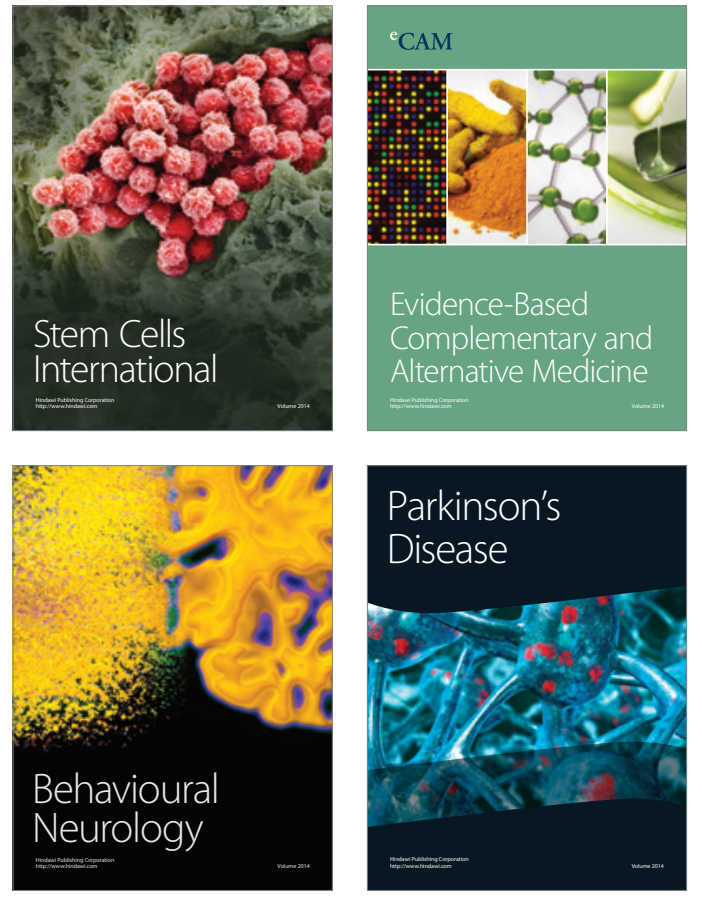
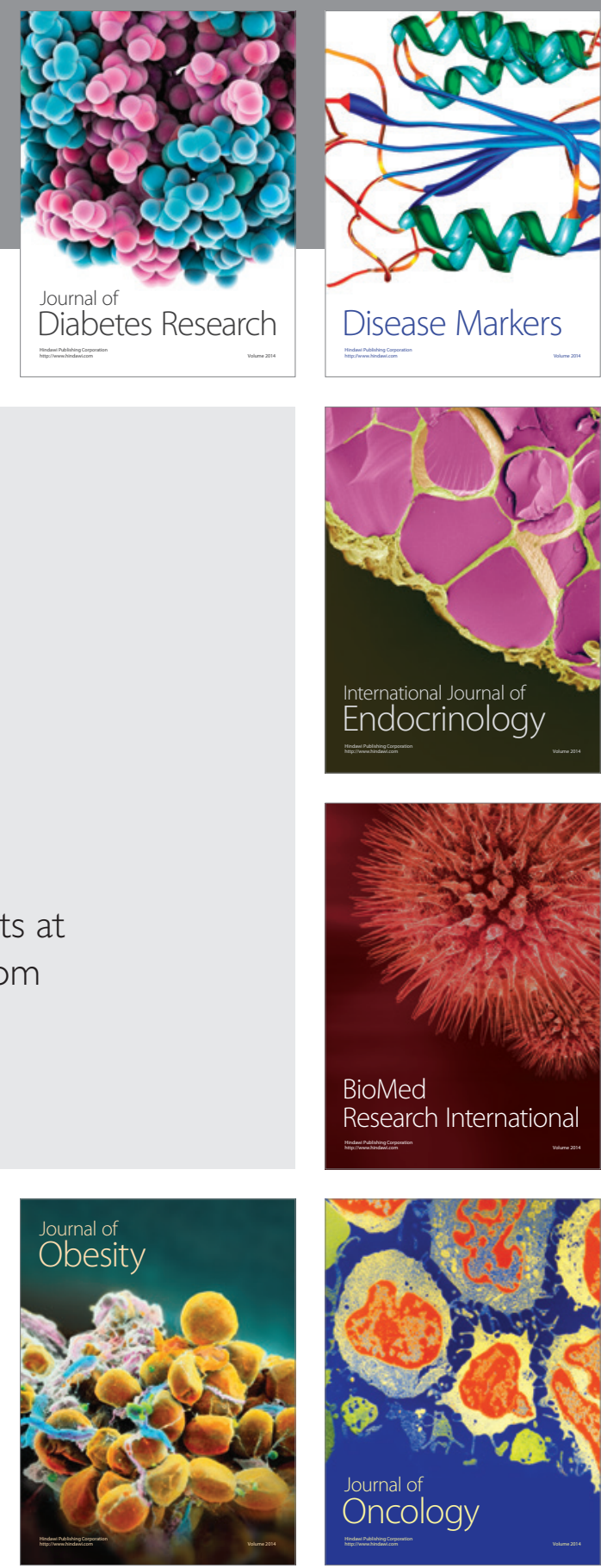

Disease Markers
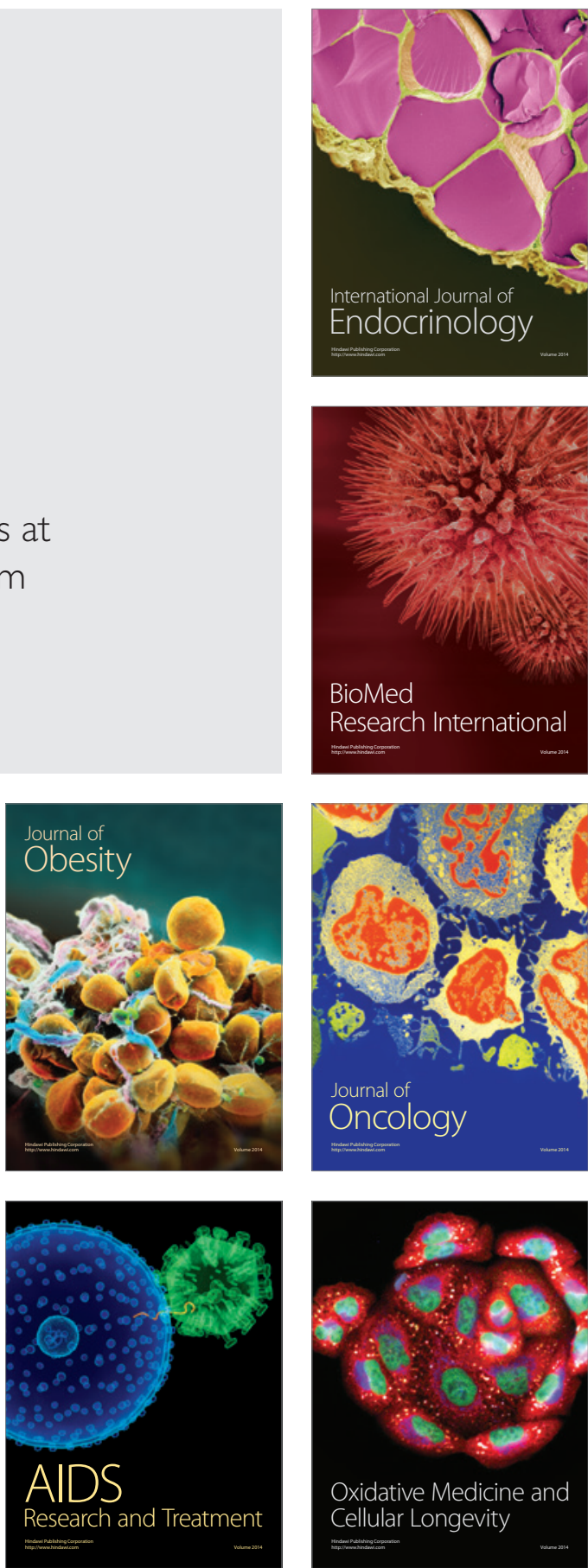